\title{
Comparison of Biological Aspects Among Ovine Luteinizing Hormone Isoforms with Charge Heterogeneity
}

\author{
YASUNORI NAKAMURA, KAORU NOMURA*, \\ Maкото WATANABE*, Makoto UJIHARA*, AND \\ Hiroshi DEMURA* \\ Research and Development Center, Calpis Food Industry Co., \\ Ltd., Tokyo 150, and *Department of Medicine, Institute of \\ Clinical Endocrinology, Tokyo Women's Medical College, Tokyo \\ 162, Japan
}

\begin{abstract}
Ovine luteinizing hormone (oLH), a pituitary hormone with sulfated asparagine-linked oligosaccharides, was examined with regard to how its isoforms having different isoelectric points (pIs) modulate in vivo biological activity. oLH was separated into five fractions by means of an isoelectric focusing (IEF) column, i.e., IEF fr 1 (pI > 10.78), IEF fr 2 (pI 10.78-10.26), IEF fr 3 (pI 10.22-10.07), IEF fr 4 (pI 9.99-9.84), and IEF fr 5 (pI 9.76-9.48). Of these, we studied the three major fractions, IEF fr 2, 3 and 4. The binding of ${ }^{125} \mathrm{I}$-oLH to rat testis homogenates was inhibited most strongly by IEF fr 4 , followed by 2 and 3. The ability to stimulate cyclic AMP release from dispersed rat Leydig cells followed the same sequence. After bolus injections of IEF fractions, the plasma immunoreactive oLH levels of male rabbits were measured. IEF fr 4 and 3 had longer plasma half-lives than 2. As expected, plasma testosterone levels after injections increased with the additive effects of in vitro activity and the rate of clearance from the circulation, i.e., IEF fr $4>3=2$. In vivo renotropic activity, ${ }^{3} \mathrm{H}$-thymidine incorporation into the renal DNA of hypophysectomized, castrated rats, was found only in IEF fr 4 . Our study indicates that an oLH isoform with a lower alkali pI had stronger LH receptor binding and in vitro bioactivity and a longer plasma half-life, resulting in stronger in vivo bioactivity.
\end{abstract}

Key words: LH, Oligosaccharide, Isoelectric point, Bioactivity, Plasma half-life.

(Endocrine Journal 40: 73-81, 1993)

LH, a glycoprotein, consists of heterodimer subunits $\alpha$ and $\beta$. Physicochemical microheterogeneity is observed both in the $\alpha$ and $\beta$ subunit polypeptide chains [1,2] and in asparagine-linked oligosaccharide chains [3, 4]. Depending on the differences in isoelectric points (pIs), LH can be separated into several isoforms. Charge heterogeneity appeared mainly attributable to the degree of terminal sulfation in oligosaccharide chains $[4,5]$.

\section{Received: July 24, 1992}

Accepted: November 20, 1992

Correspondence to: Dr. Kaoru NOMURA, Department of Medicine, Institute of Clinical Endocrinology, Tokyo Women's Medical College, 8-1 Kawada-cho, Shinjuku-ku, Tokyo 162, Japan
The change in the charge heterogeneity of pituitary LH isoforms reported due to castration [6], steroid administration [6], and unilateral nephrectomy [7] suggests that charge heterogeneity may be an expression of biological adaptation to stimuli and that individual isoforms may have different functions. In addition to porcine (p) LH, ovine (o) and bovine (b) LH oligosaccharides have also been reported to be sulfated. Human (h) LH oligosaccharides terminated with sulfate or sialic acid [8]. hCG is sialylated rather than sulfated [9]. The role of sialic acid has been studied extensively, i.e., protection of the $\mathrm{LH}$ molecule from rapid clearance via asialoglycoprotein receptors in the liver [10], but that of sulfate remains to be sufficiently clarified because of the nonavailability 
of a proper method of desulfation. Desulfated bLH has been prepared and found to be cleared more rapidly from the circulation than native $\mathrm{bLH}$, without altering receptor binding or postreceptor signal transduction [11]. Sulfation thus appears to be important to plasma clearance from the circulation and in expressing in vivo bioactivity. This issue remains to be clarified on naturally occurring LH isoforms, however. To this end, we compared the receptor binding, in vitro and in vivo bioactivity of naturally occurring oLH isoforms and their clearance from the circulation. This is the first report that compares these factors simultaneously among LH isoforms.

\section{Materials and Methods}

\section{IEF fractionation of oLH}

Lyophilized ovine pituitary gland powder was purchased from Waitaki International Biosciences, Ltd., Christchurch, New Zealand. LH (2nd G100 fr 3) was purified as reported previously [2] and was further fractionated by means of an IEF column. IEF was done with a $440 \mathrm{~m} l$ column (LKB 8100, LKB Produkter AB, Bromma, Sweden) as described earlier [4]: Briefly, ampholines $\mathrm{pH}$ 9-11, pH 3.5-10, and pH 7-9 (LKB Produkter $\mathrm{AB}$ ) were used to make up a $\mathrm{pH}$ gradient from $\mathrm{pH}$ 7 to 11 , with a sorbitol density gradient from 5 to $50 \%$. Electrofocusing for $25 \mathrm{~h}$ at $4^{\circ} \mathrm{C}$ started with $400 \mathrm{~V}$ applied, ending with $1400 \mathrm{~V}$. In this condition, standard proteins, bovine heart cytochrome with pI of 10.5 (type V, Sigma Chemical Co., St. Louis, MO, U.S.A.) and horse myoglobin with pI of 8.0 (type III, Sigma Chemical Co.), were properly eluted at $\mathrm{pH}$ of 11.01 and 8.04 , respectively. The elution pattern was monitored by measuring the protein content in each tube by Bio Rad Protein Assay (Bio-Rad Laboratories, Richmond, CA). To remove carrier ampholites and sorbitol, the pooled fraction was dialyzed against $0.5 \mathrm{M} \mathrm{NaCl}$, then distilled water; lyophilized; and purified by HPLC on a TSKG3000SW gel-filtration column (Tosoh, Tokyo, Japan). The elution buffer was $0.1 \mathrm{M}$ phosphate with $0.3 \mathrm{M} \mathrm{NaCl}$ and $2 \%$ isopropanol, $\mathrm{pH} 6.5$, with a flow rate of $0.7 \mathrm{ml} / \mathrm{min}$. The eluted protein was measured by $\mathrm{A}_{215}$ and collected. After dialysis, the protein content was measured by the Lowry method [12], using bovine serum albumin (BSA) (Nakarai Chemical Ltd., Kyoto, Japan) as a standard. The lyophilized sample was stored at $-30^{\circ} \mathrm{C}$. In our study, oLH and IEF fractions are expressed by protein content with BSA as the standard.

\section{Preparation of labeled hormone}

${ }^{125}$ I was obtained from New England Nuclear Corp., Boston, MA. oLH (2nd G100 fr 3) was iodinated by lactoperoxidase (Product No. L-2005, Sigma Chemical Co.) [13] and purified on a PD-10 column (Pharmacia Fine Chemicals, Inc., Piscataway, NJ, U.S.A.).

\section{Binding of oLH IEF fractions to testis homogenates}

Rat testis homogenates were prepared and used for the binding study as reported by Catt $e t$ al. [14], with minor modification: Briefly, adult rat testis tissues were homogenated in $10 \mathrm{ml} \mathrm{PBS} / \mathrm{g}$ tissue containing $1 \mathrm{mM}$ phenylmethylsulfonyl fluoride (PMSF). The homogenate was filtered through nylon gauze and centrifuged for $20 \mathrm{~min}$ at $1500 \times$ g. The resulting pellet was resuspended in 100

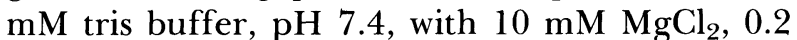
$\mathrm{mM} \mathrm{CaCl}_{2}, 0.1 \%$ BSA, $1 \mathrm{mM}$ PMSF, and $0.05 \%$ streptomycin sulfate to a protein concentration of $100 \mu \mathrm{g} / \mathrm{ml}$. Homogenates were kept at $-40^{\circ} \mathrm{C}$ until the binding study. $0.1 \mathrm{~m} l$ of the homogenate, 0.1 $\mathrm{m} l$ of the sample (IEF fraction), and $0.05 \mathrm{~m} l$ of ${ }^{125} \mathrm{I}$-oLH $(20800 \mathrm{cpm})$ were incubated overnight at room temperature, followed by centrifugation at $1500 \times \mathrm{g}$ for $30 \mathrm{~min}$. Binding at the highest dose $(200 \mathrm{ng} / \mathrm{m} l)$ represented the level of nonspecific binding. The supernatant was decanted and the radioactivity in the precipitate measured in a gammacounter.

\section{Bioassays for renotropic and gonadotropic activities}

Renotropic activity was measured by in vivo bioassay based on ${ }^{3} \mathrm{H}$-thymidine incorporation into the renal DNA of castrated, hypophysectomized rats [15]. To measure in vitro gonadotropic activity, dispersed Leydig cells were prepared from seven male rats with a body weight of $300 \mathrm{~g}$ as reported elsewhere [16]. Cells were suspended in $84 \mathrm{ml}$ of medium 199 (Sigma Chemical Co.) containing $0.1 \mathrm{mM}$ 3-isobutyl-1-methyl xanthine (Sigma Chemical Co.). $0.95 \mathrm{ml}$ of the cell suspen- 
sion was put into an assay tube containing $0.05 \mathrm{ml}$ of the sample, and was incubated in $95 \%$ of $\mathrm{O}_{2}$ and $5 \%$ of $\mathrm{CO}_{2}$ at $37^{\circ} \mathrm{C}$ for $3 \mathrm{~h}$. The reaction was stopped by centrifugation at $4^{\circ} \mathrm{C}$. The supernatant was boiled and kept at $-40^{\circ} \mathrm{C}$. cAMP was measured by specific radioimmunoassay (RIA) with a commercial RIA kit (Yamasa Shoyu Corp., Ltd., Tokyo, Japan). To estimate in vivo gonadotropic activity, serum testosterone levels were measured in male Japanese White rabbits (Nippon Ikagaku Doubutsu-shizai Laboratory, Tokyo, Japan) after the intravenous administration of $20 \mu \mathrm{g} / \mathrm{kg}$ body weight of the sample. Blood samples were collected before the injection and at 30,60, and 90 min after. Serum testosterone concentrations were measured with a commercial RIA kit (DPC Corp. Japan, Tokyo, Japan).

\section{Clearance of IEF fraction from the circulation}

Male Japanese White rabbit with a body weight of $2 \mathrm{~kg}$ were administered intravenously $14 \mu \mathrm{g} / \mathrm{kg}$ body weight of the sample dissolved in $0.5 \mathrm{ml}$ saline, then about $2.5 \mathrm{~m} l$ blood samples were taken from an ear vein at various intervals into heparinized tubes, followed by centrifugation at $1500 \times$ $\mathrm{g}$ for $10 \mathrm{~min}$. The plasma obtained was stored at $-30^{\circ} \mathrm{C}$ until assay. Plasma LH was determined by solid-phase RIA as described in the next section.

\section{oLH RIA}

Anti-oLH rabbit serum (\#1005) was generated against oLH (2nd G100 fr 3) by the method of Vaitukaitis et al. [17]. Because LH isoforms have different dose-responses in RIA, we measured the plasma levels of the injected IEF fraction by RIA with the same IEF fraction as a reference standard. RIA was as follows: $0.2 \mathrm{ml}$ of antirabbit IgG (Fc fragment, Organon Teknika Corp., West Chester, PA, U.S.A.), diluted 200 times with a 0.02 $\mathrm{M}$ phosphate buffer containing $0.15 \mathrm{M} \mathrm{NaCl}, \mathrm{pH}$ 7.4 (PBS), then incubated at room temperature for $3 \mathrm{~h}$ in $75 \times 12 \mathrm{~mm}$ plastic tubes (\#470319, A/S Nunc, Roskilde, Denmark). After washing three times with PBS, tubes were filled with PBS containing $1 \%$ casein (casein PBS) (Wako Pure Chemical Industries, Ltd., Osaka, Japan) at room temperature for $2 \mathrm{~h}$, followed by washing three times with PBS. $0.2 \mathrm{ml}$ of anti-oLH rabbit serum (\#1005) diluted $10^{5}$ times with casein PBS was added and incubated at $4^{\circ} \mathrm{C}$ overnight in antirabbit IgG-Fc fragment coated tubes, followed by washing three times with PBS. $0.1 \mathrm{ml}$ of the plasma sample was put into the tube with $0.1 \mathrm{ml}$ of casein PBS. As a standard, a lyophilized IEF fraction was dissolved in a 1:1 volume of normal rabbit plasma and casein PBS to concentrations ranging from 0.1 to 24 $\mathrm{ng} / \mathrm{m} l$. After $3 \mathrm{~h}$ incubation at room temperature, the tubes were washed three times with PBS, then $20,000 \mathrm{cpm}$ of ${ }^{125} \mathrm{I}-\mathrm{oLH}$ in $0.2 \mathrm{ml}$ of PBS was added. After $3 \mathrm{~h}$ incubation at room temperature and washing four times with PBS, radioactivity in the tubes was measured in a gamma-counter. The minimum assay sensitivity was $0.1-0.3 \mathrm{ng} / \mathrm{ml}$. Intra- and inter-assay coefficients of variation were 2.2 and $5.0 \%$. The half-life for elimination from the circulation was calculated with a onecompartment open model.

\section{Statistics}

Results were shown as means \pm SEM. Bartlett's test for uniformity of variances and Duncan's new multiple-range test were used for statistical analysis.

\section{Results}

Separation of oLH isoforms by IEF

oLH (2nd G100 fr 3) was separated into five fractions by IEF (Fig. 1). These were eluted at the following $\mathrm{pH}$ ranges; IEF fr $1>10.78$, IEF fr 2 $10.78-10.26$, IEF fr $310.22-10.07$, IEF fr 4 9.99-9.84, and IEF fr 5 9.76-9.48. IEF fractions showed identical elution patterns in reverse-phase HPLC as previously reported, indicating that they had identical polypeptide structures [2]. Differences in $\mathrm{pI}$ were thus attributable to differences in carbohydrate structure as previously shown in pLH [4]. IEF fr 1 and 5 were so minor that we did not examine them further.

\section{Testicular binding of ${ }^{125} \mathrm{I-oLH}$ and cyclic AMP stimula- tion by IEF fractions}

The binding of ${ }^{125} \mathrm{I}-\mathrm{oLH}$ to rat testicular homogenates was inhibited differently by different IEF fractions (Fig. 2). IEF fr 4 inhibited 


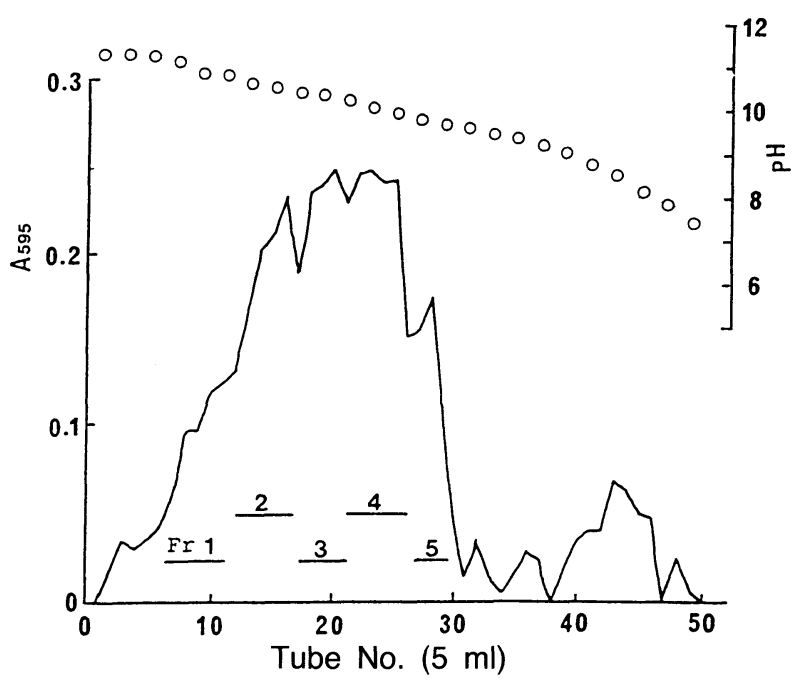

Fig. 1. Elution pattern of oLH on IEF column. $7.1 \mathrm{mg}$ of oLH (2nd G100 fr 3) was applied to the IEF column. Yields of individual fractions were: IEF fr $1152 \mu \mathrm{g}(2.1 \%)$; IEF fr $2554 \mu \mathrm{g}(7.8 \%)$; IEF fr 3 $946 \mu \mathrm{g}(13.3 \%) ;$ IEF fr $41418 \mu \mathrm{g}(20.0 \%)$; IEF fr 5 $267 \mu \mathrm{g}(3.6 \%)$; and fractions pooled after IEF fr 5 $6.4 \mu \mathrm{g}(0.1 \%)$.

binding more strongly than IEF fr 2 or 3 . This binding activity sequence indicates that these fractions stimulated cyclic AMP production in the sequence IEF fr $4>2=3$ (Fig. 3). IEF fr 4 had the same potency as 2nd G100 fr 3 .
Clearance of IEF fraction from the circulation

Each IEF fraction had a different doseresponsiveness at RIA (Fig. 4). So we measured plasma immunoreactive (ir) LH levels after intravenous injections measured by RIA with the injected IEF fraction as a reference standard. Plasma ir-oLH levels after intravenous injections of IEF fraction are shown in Fig. 5. Their plasma half-lives $\left(\mathrm{T}_{1 / 2}\right)$ are as follows; $11.7 \pm 0.8 \mathrm{~min}$ (four experiments) for IEF fr 2, 17.2 $\pm 1.1 \mathrm{~min}$ (three experiments) for IEF fr 3, and $17.0 \pm 1.2 \mathrm{~min}$ (three experiments) for IEF fr 4. IEF fractions with lower alkali pI, i.e., IEF fr 3 and 4 , had longer plasma half-lives than that with an alkali pI, i.e., IEF fr 2.

In vivo gonadotropic and renotropic activity

At 30,60 and 90 min after IEF fractions were injected intravenously at a dose of $20 \mu \mathrm{g} / \mathrm{kg}$ body weight, plasma testosterone increased significantly (Fig. 6). IEF fr 4 had the strongest in vivo gonadotropic activity of the three fractions.

In vivo renotropic activity was demonstrated only in IEF fr 4 (Fig. 7). A dosage of $70 \mu \mathrm{g}$ is sufficient to exhibit activity in renotropically active $\mathrm{LH}$ isoforms [2].

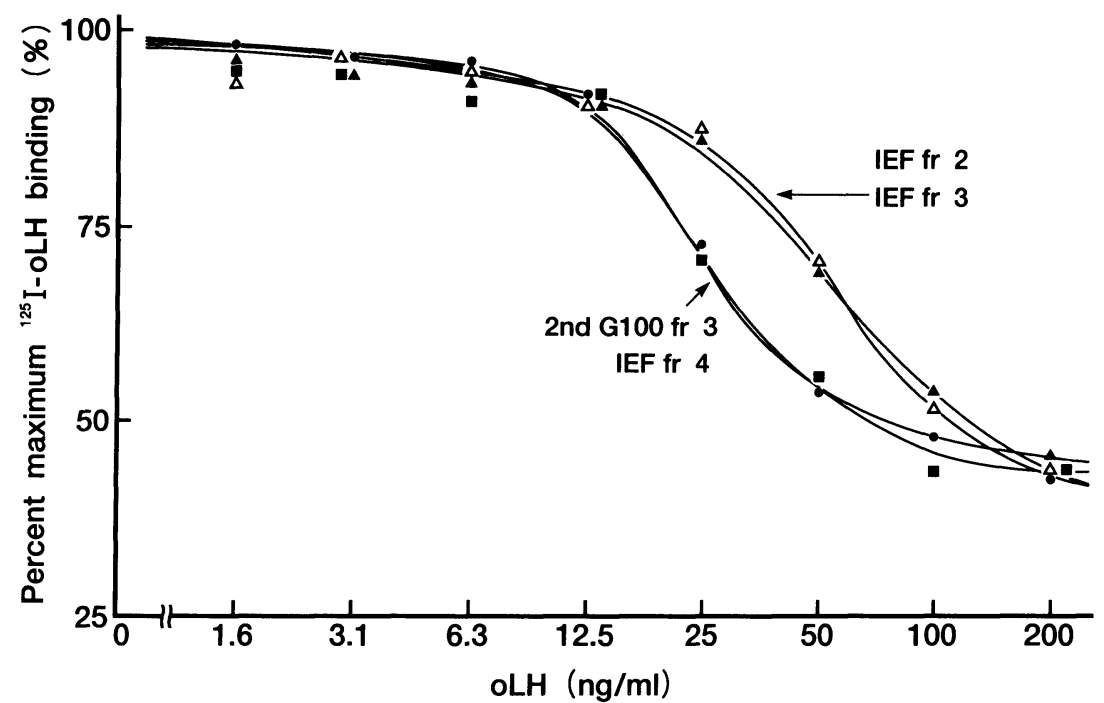

Fig. 2. ${ }^{125} \mathrm{I}$-oLH binding to testis homogenates. IEF fr 4 displaced ${ }^{125} \mathrm{I}$-oLH binding most strongly. Each point represents the mean of triplicate determinations. $20800 \mathrm{cpm}$ of ${ }^{125} \mathrm{I}$-oLH was added. ${ }^{125} \mathrm{I}$-oLH binding was $3356 \pm 44 \mathrm{cpm}$ in controls. The same results were obtained in two separate assays. 2 , 2nd G100 fr $3 ; \triangle$, IEF fr $2 ; \boldsymbol{\Delta}$, IEF fr $3 ; \boldsymbol{\square}$, IEF fr 4. 


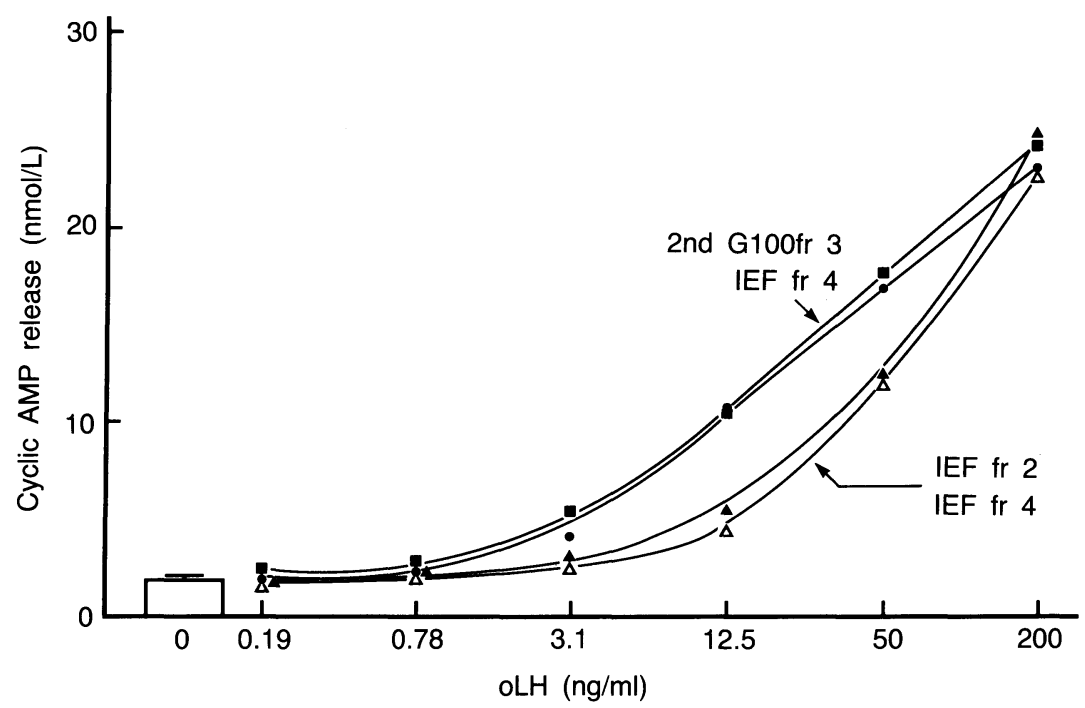

Fig. 3. In vitro gonadotropic activity of IEF fractions. Cyclic AMP release was measured in dispersed rat Leydig cells. IEF fr 4 had the strongest activity. Each point represents the mean of triplicate determinations. The same results were obtained in two separate assays. Symbols are as indicated for Fig. 2.

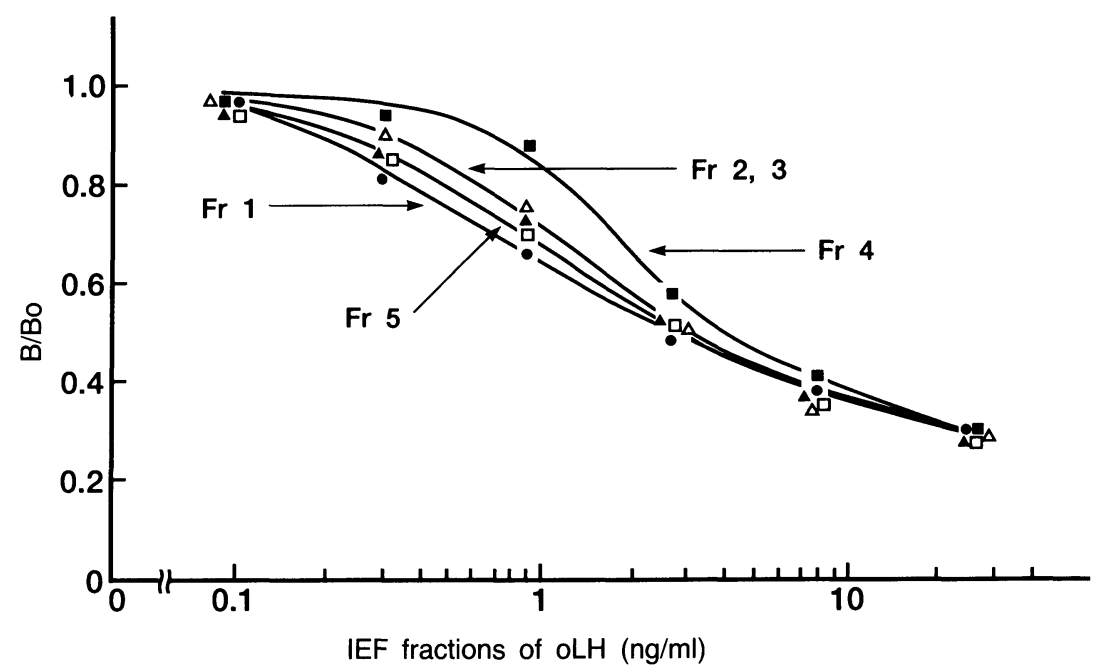

Fig. 4. IEF fractions RIA. Each fraction had distinct dose-response characteristics. Each point represents the mean of triplicate determinations. The same results were obtained in two separate assays.

\section{Discussion}

The IEF elution pattern of our oLH preparation (2nd G100 fr 3) was slightly different from that of pLH preparation purified by the same process [4]. This may be at least partially attributable to the species difference. Keel et al. applied and developed ovine pituitary extracts on a chromatofocusing column, obtaining eight ir-LH peaks
[6]. We separated purified oLH into five fractions by IEF. Although oLH could conceivably be divided into further fractions, we stopped at five to accumulate enough fractions for in vivo studies. We also considered that experiments with three major fractions would be sufficient to clarify any physiological role of charge heterogeneity, even though a fraction would be contaminated slightly with others. 


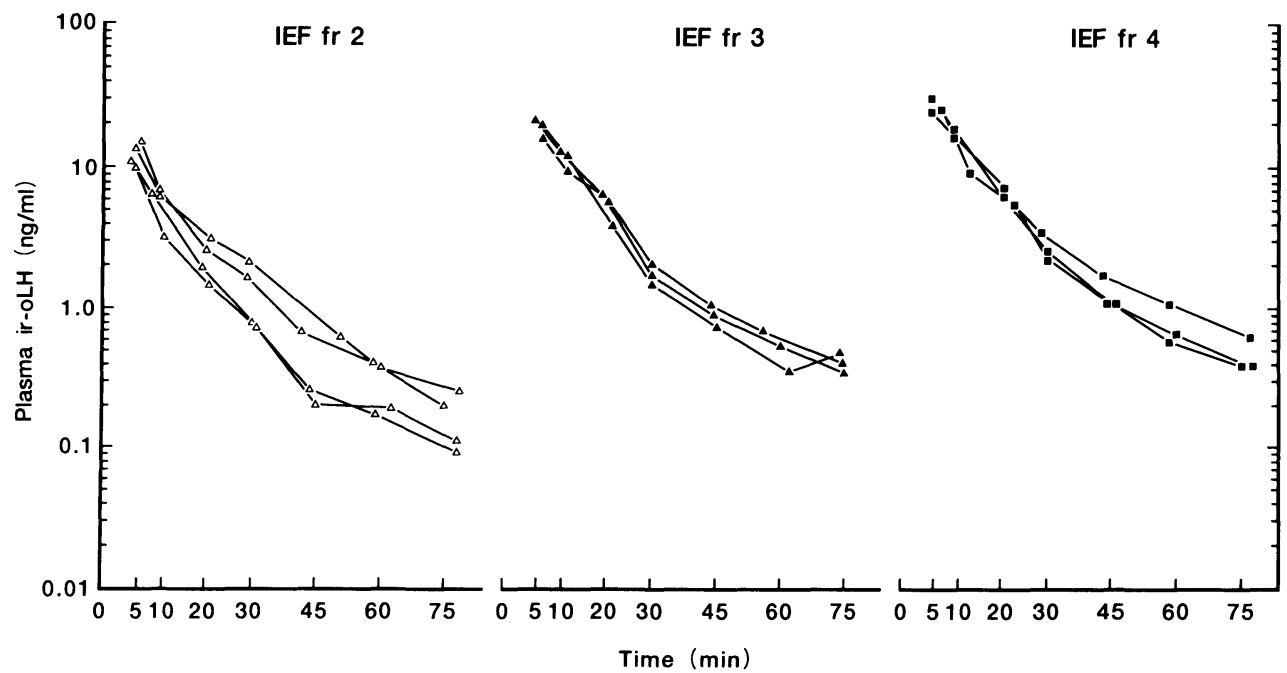

Fig. 5. Plasma half-life of IEF fractions. IEF fraction was injected intravenously into a male rabbit at a dose of $14 \mu \mathrm{g} / \mathrm{kg}$ body weight. Plasma was collected serially, and its oLH content measured by RIA as shown in Fig. 4.

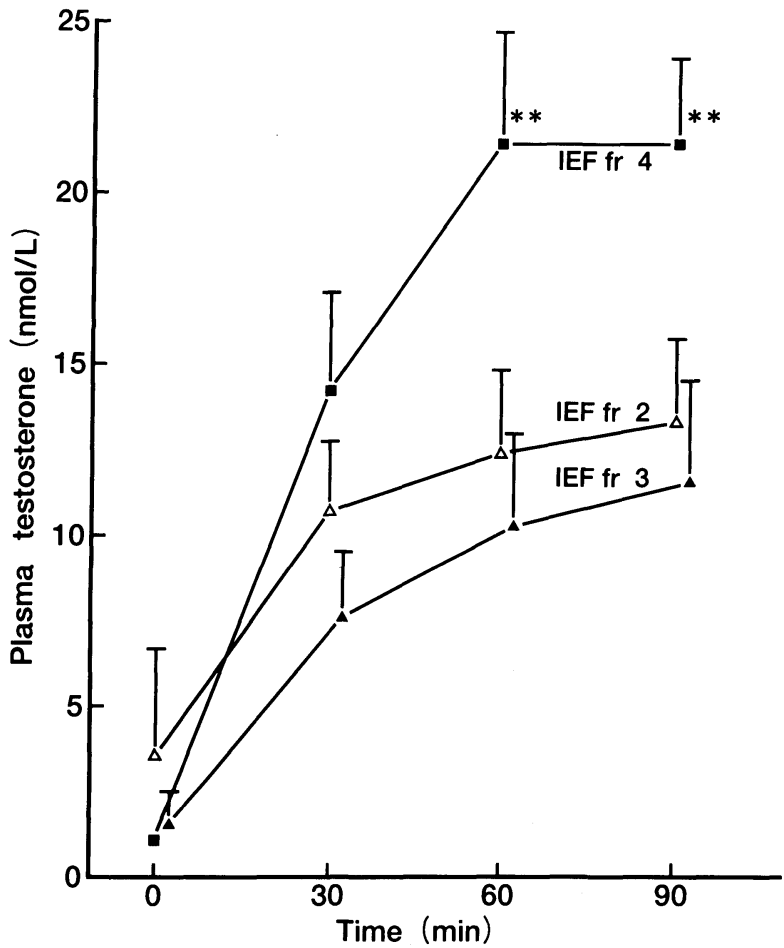

Fig. 6. Plasma testosterone levels in rabbit injected with IEF fraction. IEF fraction was injected intravenously into a male rabbit at a dose of $20 \mu \mathrm{g} / \mathrm{kg}$ body weight. Each point represents the mean \pm SEM for three assays. Plasma testosterone levels at 60 and 90 min were significantly higher in rabbits injected with IEF fr 4 than with IEF fr 2 or fr $3(P<0.01)$.

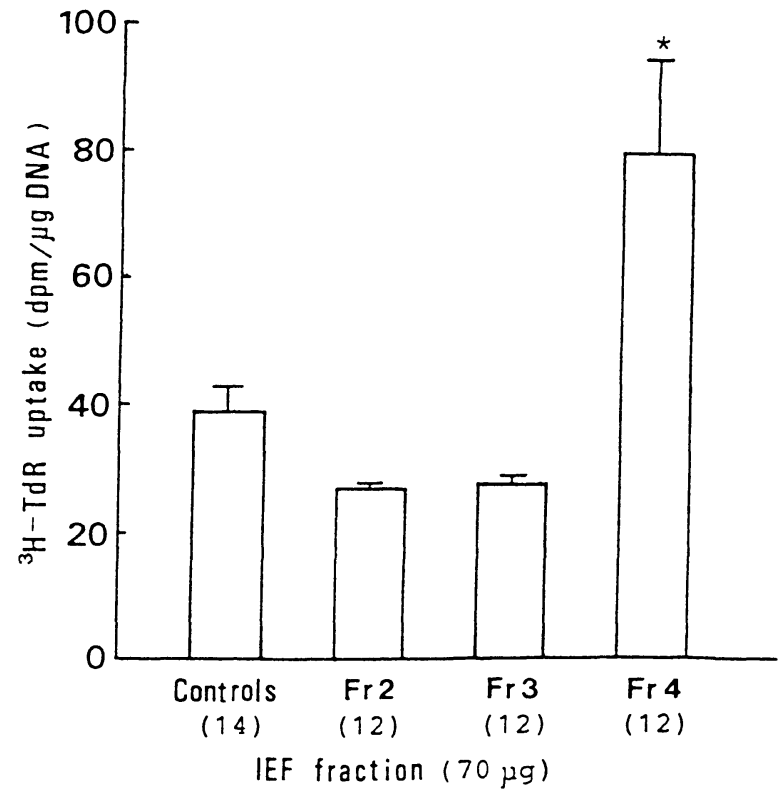

Fig. 7. Renotropic activity of IEF fraction. $70 \mu \mathrm{g}$ of IEF fraction was injected subcutaneously into castrated, hypophysectomized male rats, and rats sacrificed 8 $\mathrm{h}$ after injection. Kidney slices were prepared and incubated in ${ }^{3} \mathrm{H}$-thymidine containing buffer, then radioactivity incorporated into DNA was measured. The numbers of kidney slices are shown in parentheses. *, $P<0.05$ vs. controls. 
Our IEF fractions had different in vitro gonadotropic potency per $\mathrm{mg}$ protein. IEF fr 4 , with its lower alkali pI, bound more potently to the testicular homogenate. This probably explains why IEF fr 4 stimulated cyclic AMP production more strongly than 2 or 3 . We did not clarify in our present study whether this difference in receptor binding was sulfate-specific or a nonspecific charge-dependent effect or some other factor. Enzymatic desulfation from bLH was recently reported to not alter the binding activity to the LH receptor and in vitro gonadotropic activity [11]. It suggested that heterogeneity in binding activity may be attributable to factors other than sulfate. Further study may be necessary to characterize this desulfatase and to confirm the effect of desulfation in each isoform, in order to examine the possibility. In our previous study of the effect of pLH IEF fractions on cyclic AMP production in primary cultured rat Leydig cells, we reported that IEF fraction with a lower alkali pI had weaker in vitro gonadotropic activity [4]. Our present study showed otherwise, i.e., that oLH IEF fraction with a lower alkali pI had stronger in vitro gonadotropic activity. In our previous study with pLH isoforms, we purified pLH IEF fractions by dialysis alone, without gel-filtration HPLC, to remove ampholines, and found that dialysis could not completely remove ampholines from IEF fractions and that these ampholines may interfere with in vitro bioactivity. Other factors, however, may cause such a difference. The most potent isoform, IEF fr 4 , failed to have a higher potency than 2nd G100 fr 3 , presumably because IEF fr 4 was a major fraction (41.8\% of the sum of all IEF fractions). We also found that IEF fractions had different dose-characteristics at RIA, as reported by others $[18,19]$. ir-LH levels thus may be influenced by oligosaccharide heterogeneity. This is important because GnRH and sex steroids directly affect the glycosylation of the LH molecule [20, 21]. Thus, the conventional assay, in which the bioactive/ immunoreactive $(\mathrm{B} / \mathrm{I}) \mathrm{LH}$ ratio is calculated, does not appear to be accurate enough to precisely estimate the biological potency of the $\mathrm{LH}$ molecule.

Presumably because of the difficulty in preparing sufficient amounts, the in vivo activity of naturally occurring oLH isoforms has never been reported despite important endocrinological implications. Our findings demonstrate that an IEF fraction with a low alkali pI (IEF fr 4) had a longer plasma half-life than one with a high alkali pI (IEF fr 2). Thus, IEF fr 4 had the strongest in vitro bioactivity and stayed longest in the circulation, resulting in the strongest in vivo gonadotropic activity, estimated from the plasma testosterone levels. The plasma disappearance curve of ${ }^{3} \mathrm{H}$ oLH was reported to consist of at least two components when injected into intact male rats, i.e., a fast phase with a $T_{1 / 2}$ of $5 \mathrm{~min}$ and a slow phase with a $\mathrm{T}_{1 / 2}$ of $29 \mathrm{~h}$ [22]. Other researchers injecting rats with ${ }^{125} \mathrm{I}-\mathrm{bLH}$ found the fast and slow phases of the plasma half-lives of ${ }^{125} \mathrm{I}$-bLH to be $1.2 \mathrm{~min}$ and $27 \mathrm{~min}$ [11]. When sheep received a bolus injection of ovine pituitary extract and the plasma ir-oLH concentration was measured, the $T_{1 / 2}$ of the fast and slow phases was estimated to be $39.3 \mathrm{~min}$ and $878 \mathrm{~min}$ [23]. Thus, estimation of the plasma half-life depends on the method used, i.e., the animal species, injected materials, and assay methods. It may be important to compare the relative plasma half-lives of IEF fractions in the same assay. Desulfated bLH was reported to be cleared rapidly from the circulation, suggesting that a more sulfated molecule has a slower clearance rate [11]. Our data for comparing naturally present LH isoforms is consistent with this concept.

oLH is mainly distributed to and broken down in the kidney and liver [22]. Changes in the asparagine-linked oligosaccharide structure were reported to alter tissue distribution of the $\mathrm{LH}$ molecule, e.g., glycoproteins terminated in galactosyl [24] or N-acetylglucosaminyl [25, 26] residues were mainly taken up in the liver. Glycoprotein terminated in mannosyl residues was mainly taken up in the kidneys $[25,26]$. A specific receptor for sulfated oligosaccharide has been found in the liver [27]. oLH oligosaccharides reportedly terminate mainly with the sulfate and slightly with either $\mathrm{N}$-acetyl-galactosamine, sialic acid, galactose, or mannose $[8,28]$. Thus, terminal oligosaccharide residue heterogeneity among IEF fractions may affect the distribution of the $\mathrm{LH}$ molecule in the kidneys and liver. It remains unclear, however, whether the expression of renotropic activity by IEF fr 4 is related to this distribution pattern. From the study in which renotropic activity between hCG and oLH subunits was examined in hybrids, we found that the renotropic activity was reconstituted in hybrids 
which contained at least one oLH-derived subunit [29]. Therefore, renotropic activity was not necessarily correlated with the degree of sulfation or the charge of the whole oLH molecule. This may explain why renotropic activity in pLH was exhibited in a $\mathrm{pH}$ range (10.28-10.18) different from that in oLH [4].

In summary, our study confirmed that oLH isoforms with different charges had distinct LH receptor binding, in vitro bioactivity and plasma clearance rates. An isoform with a lower alkali pI, most likely due to the degree of sulfation, is the strongest in stimulating in vivo testosterone secre- tion because of the additive effects of stronger binding to the receptor and in vitro activity and of slower clearance from the circulation.

\section{Acknowledgments}

We thank Dr. Kazutaka Ohmura, Calpis Food Industry Co., Ltd., for his technical advice and Ms. Jun Setoguchi for editing the manuscript. This work was supported in part by the Foundation of Growth Science, Japan.

\section{References}

1. Ward DN, Bousfield GR, Gordon WL, Sugino H (1989) Chemistry of the peptide components of glycoprotein hormones. In: Keel BA, Grotjan HE, Jr. (eds) Microheterogeneity of Glycoprotein Hormones. CRC Press, Inc., Boca Raton, Florida, $1-22$.

2. Nomura K, Tsunasawa S, Ohmura K, Sakiyama F, Shizume K (1988) Renotropic activity in ovine luteinizing hormone isoform(s). Endocrinology 123: 700-712.

3. Grotjan HE, Jr. (1989) Oligosaccharide structures of the anterior pituitary and placental glycoprotein hormones. In: Keel BA, Grotjan HE, Jr. (eds) Microheterogeneity of Glycoprotein Hormones. CRC Press, Inc., Boca Raton, Florida, 1-22.

4. Nomura K, Ohmura K, Nakamura Y, Horiba N, Shirakura Y, Sato Y, Ujihara M, Ohki K, Shizume $\mathrm{K}$ (1989) Porcine luteinizing hormone isoform(s): Relationship between their molecular structures, and renotropic versus gonadotropic activities. Endocrinology 124: 712-719.

5. Ujihara M, Yamamoto K, Nomura K, Toyoshima S, Demura H, Nakamura Y, Ohmura K, Osawa T (1992) Subunit-specific sulfation of oligosaccharides relating to charge-heterogeneity in porcine lutropin isoforms. Glycobiology 2: 225-231.

6. Keel BA, Schanbacher BD, Grotjan HE Jr. (1987) Ovine luteinizing hormone. Effects of castration and steroid administration on the charge heterogeneity of pituitary luteinizing hormone. Biol Reprod 36: 1102-1113.

7. Ujihara $\mathbf{M}$, Nomura $\mathrm{K}$, Toraya S, Demura $\mathrm{H}$ (1990) Uninephrectomy inducing qualitative and quantitative changes in $\mathrm{LH}$ isoforms in male rats. Acta Endocrinol 123: 365-370.

8. Baenziger JU (1990) The asparagine-linked oligosaccharides of the glycoprotein hormones. In: Chin WW, Boime I (eds) Glycoprotein Hormones.
Serono Symposia, USA, Norwell, Massachusetts, 11-18.

9. Kobata A (1990) Structures and function of the sugar chains of human chorionic gonadotropin. In: Chin WW, Boime I (eds) Glycoprotein Hormones. Serono Symposia, USA, Norwell, Massachusetts, 19-26.

10. Kalyan NK, Lippes HA, Bahl OP (1982) Role of carbohydrate in human chorionic gonadotropin. $J$ Biol Chem 257: 12624-12631.

11. Baenziger JU, Kumar S, Brodbeck RM, Smith PL, Beranek MC (1992) Circulatory half-life but not interaction with the lutropin/chorionic gonadotropin receptor is modulated by sulfation of bovine lutropin oligosaccharides. Proc Natl Acad Sci USA 89: 334-338.

12. Lowry $\mathrm{OH}$, Rosebrough NJ, Farr AL, Randall RJ (1951) Protein measurement with the folin phenol reagent. J Biol Chem 193: 265-275.

13. Miyachi Y, Chrambach A, Mecklenburg R, Lipsett MB (1973) Preparation and properties of ${ }^{125} \mathrm{I}-\mathrm{LH}-$ RH. Endocrinology 92: 1725-1730.

14. Catt KJ, Tsuruhara T, Dufau ML (1972) Gonadotropin binding sites of the rat testis. Biochim Biophys Acta 279: 194-201.

15. Nomura K, Demura H, Shizume K (1985) Stimulation of renal deoxyribonucleic acid synthesis by a pituitary-derived renotropin and its inhibition by testosterone and thyroxine. Endocrinology 116: 616-621.

16. Dufau ML, Mendelson CR, Catt KJ (1974) A highly sensitive in vitro bioassay for luteinizing hormone and chorionic gonadotropin: testosterone production by dispersed Leydig cells. J Clin Endocrinol Metab 39: 610-613.

17. Vaitukaitis J, Robbins JB, Nieschlag E, Ross GT (1971) A method for producing specific antisera with small doses of immunogen. J Clin Endocrinol 
33: 988-991.

18. Jaakkola T, Ding Y-Q, Kellokumpu-Lehtinen $\mathrm{P}$, Valavaar R, Martikainen H, Tapanainen J, Ronnennerg L, Huhtaniema I (1990) The ratio of serum bioactive/immunoreactive luteinizing hormone and follicle-stimulating hormone in various clinical conditions with increased and decreased gonadotropin secretion: Reevaluation by a highly sensitive immunometric assay. J Clin Endocrinol Metab 70: 1496-1505.

19. De Hertogh R, Wolter R, Vliet V, Vankrieken L (1989) Serum gonadotropins levels in childhood. Critical comparison between immunoradiometric assays and radioimmunoassays. Acta Endocrinol (Copenh) 121: 141-146.

20. Wilson CA, Leigh AJ, Chapman AJ (1990) Gonadotrophin glycosylation and function. J Endocrinol 125: 3-14.

21. Krummen LA, Baldwin DM (1988) Regulation of luteinizing hormone subunit biosynthesis in cultured male anterior pituitary cells: Effects of gonadotropin-releasing hormone and testosterone. Endocrinology 123: 1868-1878.

22. Ascoli M, Liddle RA, Puett D (1974) The metabolism of luteinizing hormone. Plasma clearance, urinary excretion, and tissue uptake. Mol Cell Endocrinol 3: 21-36.

23. Robertson DM, Foulds LM, Fray RC, Cummins JT, Clarke I (1991) Circulating half-lives of folliclestimulating hormone and luteinizing hormone in pituitary extracts and isoform fractions of ovariectomized and intact ewes. Endocrinology 129: 1805-1813.

24. Hudgin RL, Pricer WE, Ashwell G, Stockert RJ, Morell AG (1974) The isolation and properties of a rabbit liver binding protein specific for asialoglycoproteins. J Biol Chem 249: 5536-5543.

25. Stockert RJ, Morell AG, Scheinberg IH (1976) The existence of a second route for the transfer of certain glycoproteins from the circulation into the liver. Biochem Biophys Res Commun 68: 988-993.

26. Winkelhake JL, Nicolson GL (1976) Aglycosylantibody. Effect of exoglycosidase treatments on autochthonous antibody survival time in the circulation. J Biol Chem 251: 1074-1080.

27. Fiete D, Srivastava V, Hindsgaul O, Baenziger JU (1991) A hepatic reticuloendothelial cell receptor specific for $\mathrm{SO}_{4}-4 \mathrm{GalNAc} \beta 1$, 4GlcNAc $\beta 1$, $2 \mathrm{Man} \alpha$ that mediates rapid clearance of lutropins. Cell 67: 1103-1110.

28. Weisshaar G, Hiyama J, Renwick GC (1990) Sitespecific N-glycosylation of ovine lutropin. Structure analysis by one- and two-dimensional ${ }^{1} \mathrm{H}$ NMR spectroscopy. Eur J Biochem 192: 741-751.

29. Nomura K, Nakamura Y, Ujihara M, Ohmura K, Toraya S, Horiba N, Demura H (1991) Renotropic and gonadotropic activity in homologous and heterologous hybrids of ovine luteinizing hormone and human chorionic gonadotropin subunits. Acta Endocrinol (Copenh) 125: 590-594. 